\title{
Synthesis and Study of Cell-Penetrating Peptide-Modified Gold Nanoparticles [Corrigendum]
}

\author{
Boussoufi F, Navarro Gallón SM, Chang R, Webster TJ. \\ Int J Nanomedicine. 2018;13:6199-6205.
}

The authors have advised Figure 3 on page is incorrect. The authors inadvertently duplicated the image for Figure 3B (PEP-AuNPs immediately after the synthesis) and
Figure 3D (PEP-AuNPs after centrifugation). The correct Figure 3 is as follows.

The authors advise this does not change the conclusions of the paper. 

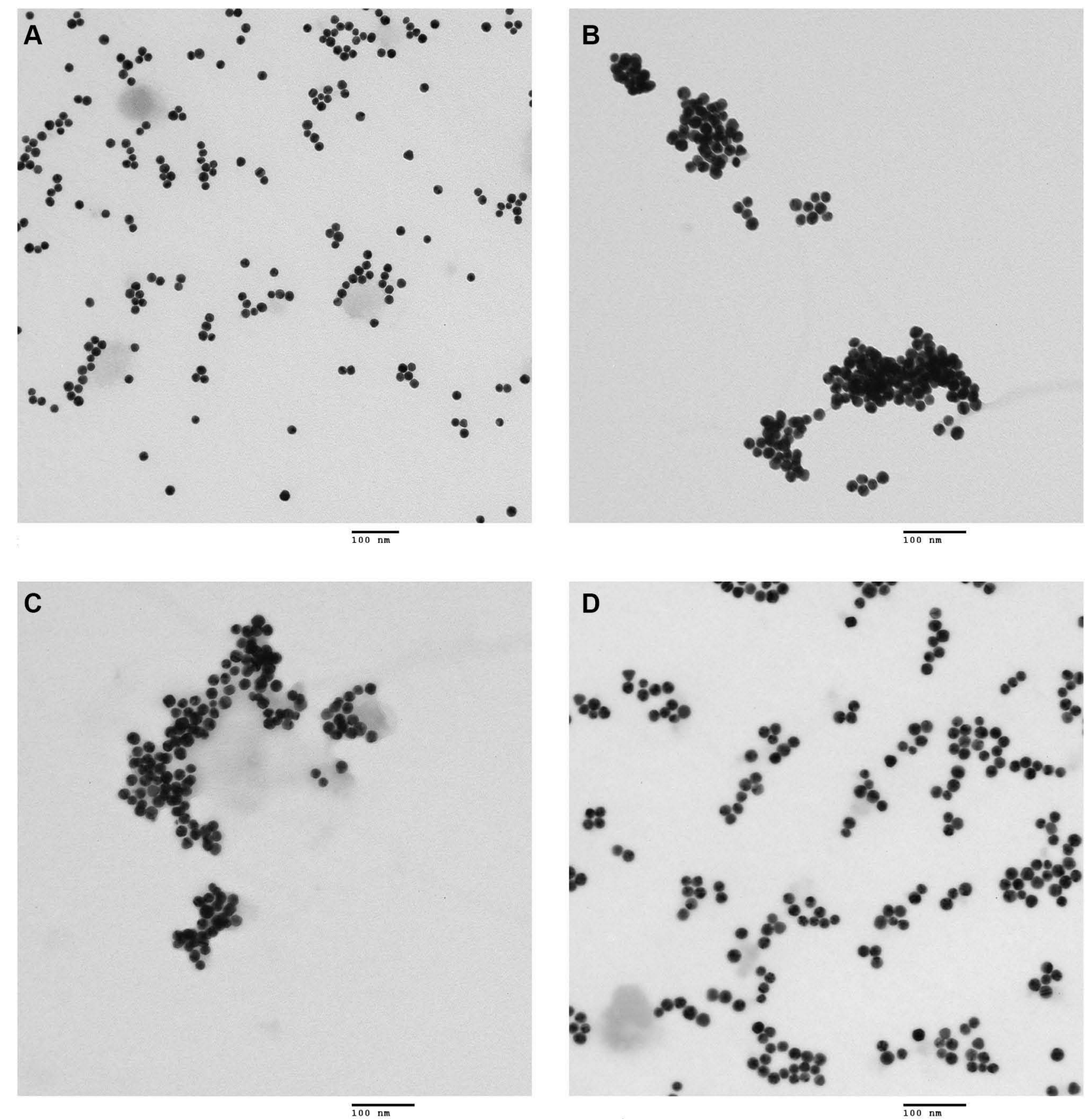

Figure 3 TEM images of AuNPs: (A) pure AuNPs in citrate buffer, (B) PEP-AuNPs immediately after the synthesis, (C) PEP-AuNPs before centrifugation, (D) and PEPAuNPs after centrifugation.

Note: Scale bars $=100 \mu \mathrm{m}$.

Abbreviations: AuNP, gold nanoparticle; PEP-AuNP, peptide-capped AuNP; TEM, transmission electron microscopy.

International Journal of Nanomedicine

Dovepress

\section{Publish your work in this journal}

The International Journal of Nanomedicine is an international, peerreviewed journal focusing on the application of nanotechnology in diagnostics, therapeutics, and drug delivery systems throughout the biomedical field. This journal is indexed on PubMed Central, MedLine, CAS, SciSearch ${ }^{\mathbb{B}}$, Current Contents ${ }^{\mathbb{B}} /$ Clinical Medicine,
Journal Citation Reports/Science Edition, EMBase, Scopus and the Elsevier Bibliographic databases. The manuscript management system is completely online and includes a very quick and fair peer-review system, which is all easy to use. Visit http://www.dovepress.com/ testimonials.php to read real quotes from published authors. 